\title{
PENGARUH KUALITAS PELAYANAN DAN KUALITAS PRODUK TERHADAP KEPUTUSAN PEMBELIAN KONSUMEN SEPEDA MOTOR HONDA DI PT PANCA SAKTI PERKASA DI BINTARO
}

\author{
${ }^{1 *}$ Heri Erlangga, ${ }^{2}$ Nurjaya, ${ }^{3}$ Denok Sunarsi, ${ }^{4}$ Mahnun Mas'adi, ${ }^{5}$ Jasmani \\ ${ }_{1}^{1}$ Universitas Pasundan, Bandung, Jawa Barat, Indonesia \\ ${ }^{2}$ Universitas Suryakancana, Cianjur, Jawa Barat, Indonesia \\ 3.4.5Universitas Pamulang, Tangerang Selatan, Banten, Indonesia \\ *heri.erlangga@unpas.ac.id
}

\begin{abstract}
Abstrak
Penelitian ini bertujuan untuk mengetahui pengaruh kualitas pelayanan dan kualitas produk terhadap keputusan pembelian konsumen pada PT. Panca Sakti Perkasa di Bintaro. Teknik analisis menggunakan analisis statistik dengan pengujian regresi, korelasi, determinasi dan uji hipotesis. Hasil penelitian ini kualitas pelayanan berpengaruh signifikan terhadap keputusan pembelian sebesar 45,3\%, uji hipotesis diperoleh $\mathrm{t}$ hitung $>\mathrm{t}$ tabel atau $(9,001>1,984)$. Kualitas produk berpengaruh signifikan terhadap keputusan pembelian sebesar $44,2 \%$, uji hipotesis diperoleh $\mathrm{t}$ hitung $>\mathrm{t}$ tabel atau $(8,806>$ 1,984). Kualitas pelayanan dan kualitas produk secara simultan berpengaruh signifikan terhadap keputusan pembelian dengan persamaan regresi $Y=10,553+0,365 X 1+0,378 X 2$. Kontribusi pengaruh sebesar 53,6\%, uji hipotesis diperoleh F hitung > F tabel atau $(56,081>2,700)$.
\end{abstract}

Kata Kunci: Kualitas Pelayanan, Kualitas Produk, Keputusan Pembelian

\section{Abstract}

This research aims to find out the influence of service quality and product quality on consumer purchasing decisions on PT. Panca Sakti Perkasa in Bintaro. Analytical techniques use statistical analysis with regression testing, correlation, determination and hypothesis testing. The results of this study of quality of service significantly affect purchasing decisions by $45.3 \%$, hypothesis tests obtained $t$ calculate $>t$ table or $(9,001>$ 1,984). Product quality significantly affects purchasing decisions by $44.2 \%$, hypothesis tests obtained t calculate $>t$ table or $(8,806>1,984)$. Service quality and product quality simultaneously have a significant effect on purchasing decisions with regression equation $Y=10.553+0.365 X 1+0.378 X 2$. The contribution of influence is $53.6 \%$, the hypothesis test obtained F calculates $>F$ table or $(56,081>2,700)$.

Keywords: Quality of Service, Quality of Products, Purchasing Decisions

\section{PENDAHULUAN}

Industri otomotif dapat digolongkan menjadi beberapa jenis, diantaranya adalah industri sepeda motor dan industri mobil. Meningkatnya mobilitas masyarakat pada saat ini dan didukung dengan kurang representatifnya transportasi umum di Indonesia para pelaku membuat industri otomotif mobil maupun sepeda motor berkembang dengan pesat. Pemerintah dianggap tidak mampu untuk memberikan pelayanan transportasi yang baik kepada masyarakat. Hal ini menjadikan masyarakat memiliki keinginan yang tinggi untuk menggunakan kendaraan pribadi baik kendaraan roda dua maupun roda empat, hal tersebut menjadi salah satu alasan industri ini mengalami pertumbuhan yang pesat.

Kemunculan kendaraan roda dua membuktikan bahwa sepeda motor bukan hanya alat transportasi gerak cepat, melainkan alat transportasi yang praktis dan terjangkau. Sepeda motor merupakan jenis kendaraan yang biasa dimiliki oleh berbagai kalangan ekonomi, mulai dari kalangan atas, menengah, bahkan kalangan ekonomi bawahpun juga tidak sedikit yang memiliki kendaraan roda dua. Dengan semakin beragamnya permintaan konsumen membuat para pengusaha 
berlomba-lomba untuk mendapatkan simpati serta loyalitas dari calon pelanggannya. Bila konsumen telah memutuskan untuk menjadi pelanggan maka bisa dipastikan mereka akan membeli produk yang diproduksi dari perusahaan tersebut.

Kualitas produk merupakan salah satu faktor yang menjadi pertimbangan konsumen sebelum membeli suatu produk. Untuk kualitas produk sendiri Honda dikenal sebagai motor yang irit, mesin yang bandel dan suku cadang yang awet. Dengan kualitas produk yang bagus dan terpercaya, maka produk akan senantiasa tertanam dibenak konsumen, karena konsumen bersedia membayar sejumlah uang untuk membeli produk yang berkualitas.

Setelah melihat kualitas dari produk yang ditawarkan, maka dengan sendirinya konsumen akan mencoba membandingkan kualitas layanan yang diberikan, dan dalam hal ini perusahaan dituntut untuk memberikan kualitas layanan yang mampu mempegaruhi nilai yang lebih, sehingga berbeda dengan kualitas layanan persaing sehingga kualitas pelayanan menjadi salah satu faktor pertimbangan konsumen sebelum membeli produk. Dengan kualitas layanan yang memuaskan, mendorong konsumen untuk melakukan pembelian produk yang bersangkutan. Jika suatu perusahaan mampu memberikan pelayanan yang baik, secara langsung atau tidak langsung, citra layanannya akan tersebar luas karena kepuasan yang dirasakan pelanggannya akan disampaikan pelanggan yang satu ke pelanggan lainnya secara berantai, sehingga dapat menarik pelanggan yang lebih banyak.

Dealer atau showroom adalah salah satu layanan purna jual yang diberikan oleh PT. Panca Sakti Perkasa untuk mempermudah konsumen untuk melihat dan mencari informasi produk yang ditawarkan, serta melakukan pembelian. Honda Bintaro. Kondisi saat ini penjualan mengalami penurunan dibandingkan dengan waktu-waktu sebelumnya. Kondisi penurunan tersebut jelas akan mengganggu tingkat keuntungan yang diharapkan oleh perusahaan dan hal ini harus segera dapat dibenahi agar tidak mengalami penurunan secara terus menerus.

Berdasarkan data informasi tersebut, maka maka penulis tertarik melakukan penelitian berjudul: "Pengaruh kualitas pelayanan dan kualitas produk terhadap keputusan pembelian konsumen sepeda motor Honda di PT. Panca Sakti Perkasa di Bintaro".

\section{TINJAUAN PUSTAKA}

\section{Kualitas pelayanan}

Pelanggan tertarik membeli sebuah produk atau jasa karena kualitas layanan yang baik. Menurut Tjiptono (2019:59) menyatakan bahwa "Kualitas pelayanan adalah tingkat keunggulan yang diharapkan dan pengendalian atas tingkat keunggulan tersebut untuk memenuhi keinginan pelanggan".

\section{Kualitas produk}

Menurut Kotler dan Armstrong (2019:349) “Kualitas Produk merupakan sesuatu yang bisa ditawarkan kepasar untuk diperhatikan, dimiliki, digunakan, atau dikonsumsi yang bias memuaskan keinginan dan kebutuhan".

\section{Keputusan pembelian}

Keputusan pembelian merupakan bagian dari perilaku konsumen perilaku konsumen yaitu studi tentang bagaimana individu, kelompok, dan organisasi memilih, membeli, menggunakan, dan bagaimana barang, jasa, ide atau pengalaman untuk memuaskan kebutuhan dan keinginan mereka, Kotler dan Armstrong (2017:177).

\section{METODE}

\section{Jenis Penelitian}

Jenis penelitian ini adalah kuantitatif, menurut Sugiyono (2018:8) penelitian kuantitatif adalah: "Metode penelitian yang berlandaskan pada filsafat positivisme, digunakan untuk meneliti pada populasi atau sampel tertentu, pengumpulan data menggunakan instrument penelitian, 
analisis data bersifat kuantutatif atau statistik, dengan tujuan untuk menguji hipotesis yang telah ditetapkan. Populasi dan sampel dalam penelitian berjumlah 100 responden.
HASIL DAN PEMBAHASAN

\section{Analisis Deskriptif}

Pada pengujian ini digunakan untuk mengetahui skor minimum dan maksimum, mean score dan standar deviasi dari masing-masing variabel. Adapun hasilnya sebagai berikut:

Tabel 1. Hasil Analisis Descriptive Statistics

Descriptive Statistics

\begin{tabular}{lc|r|r|r|r} 
& N & Minimum & Maximum & Mean & \multicolumn{1}{c}{ Std. Deviation } \\
\hline $\begin{array}{l}\text { Kualitas pelayanan } \\
(X 1)\end{array}$ & 100 & 31 & 48 & 37.84 & 4.054 \\
\hline Kualitas produk (X2) & 100 & 27 & 46 & 38.20 & 3.682 \\
\hline $\begin{array}{l}\text { Keputusan pembelian } \\
(Y)\end{array}$ & 100 & 32 & 46 & 38.79 & 3.580 \\
\hline Valid N (listwise) & 100 & & & & \\
\hline
\end{tabular}

Kualitas pelayanan diperoleh varians minimum sebesar 31 dan varians maximum 48 dengan mean score sebesar 3,784dengan standar deviasi 4,054.

Kualitas produk diperoleh varians minimum sebesar 27 dan varians maximum 46 dengan mean score sebesar 3,828 dengan standar deviasi 3,682.

Keputusan pembelian diperoleh varians minimum sebesar 32 dan varians maximum 46 dengan mean score sebesar
3,879 dengan standar deviasi 3,580.

\section{Analisis Kuantitatif}

Pada analisis ini dimaksudkan untuk mengetahui pengaruh variabel independen terhadap variabel dependen. Adapun hasil pengujian sebagai berikut:

\section{a. Analisis Regresi Linier Berganda}

Hasil Pengujian regresi linier berganda sebagai berikut:

Tabel 2. Hasil Pengujian Regresi Linier Berganda

Coefficients $^{a}$

Unstandardized Standardized

\begin{tabular}{|c|c|c|c|c|c|c|}
\hline \multirow{2}{*}{\multicolumn{2}{|c|}{ Model }} & \multicolumn{2}{|c|}{ Coefficients } & \multirow{2}{*}{$\begin{array}{c}\text { Coefficients } \\
\text { Beta } \\
\end{array}$} & \multirow[b]{2}{*}{$\mathrm{t}$} & \multirow[b]{2}{*}{ Sig. } \\
\hline & & $\mathrm{B}$ & Std. Error & & & \\
\hline \multirow[t]{3}{*}{1} & (Constant) & 10.553 & 2.701 & & 3.907 & .000 \\
\hline & $\begin{array}{l}\text { Kualitas pelayanan } \\
\text { (X1) }\end{array}$ & .365 & .082 & .413 & 4.446 & .000 \\
\hline & Kualitas produk (X2) & .378 & .090 & .389 & 4.183 & .000 \\
\hline
\end{tabular}

Berdasarkan hasil pengujian pada tabel di atas, diperoleh persamaan regresi $\mathrm{Y}=10,553+$ 0,365X1 + 0,378X2. Dari persamaan tersebut dijelaskan sebagai berikut:

1) Konstanta sebesar 10,553 diartikan jika kualitas pelayanan dan kualitas produk tidak ada, maka telah terdapat nilai keputusan pembelian sebesar 10,553 point.

2) Koefisien regresi kualitas pelayanan sebesar 0,365 , angka ini positif artinya setiap ada peningkatan kualitas pelayanan sebesar 0,365 maka keputusan pembelian juga akan mengalami peningkatan sebesar 0,365 point.

3) Koefisien regresi kualitas produk sebesar 0,378, angka ini positif artinya setiap ada peningkatan kualitas produk sebesar 0,378 maka keputusan pembelian juga akan mengalami peningkatan sebesar 0,378 point.

\section{b. Analisis Koefisien Korelasi}

Hasil pengujian koefisien korelasi sebagai berikut: 
Tabel 3. Hasil Pengujian Koefisien Korelasi Kualitas pelayanan Terhadap Keputusan pembelian.

Correlations $^{b}$

\begin{tabular}{llr|r} 
& & $\begin{array}{c}\text { Kualitas } \\
\text { pelayanan } \\
(\mathrm{X} 1)\end{array}$ & \multicolumn{2}{c}{$\begin{array}{c}\text { Keputusan } \\
\text { pembelian }(\mathrm{Y})\end{array}$} \\
\hline Kualitas pelayanan (X1) & $\begin{array}{l}\text { Pearson } \\
\text { Correlation }\end{array}$ & 1 & $.673^{\text {** }}$ \\
\cline { 2 - 4 } & Sig. (2-tailed) & & .000 \\
\hline Keputusan pembelian (Y) & $\begin{array}{l}\text { Pearson } \\
\text { Correlation }\end{array}$ & $.673^{\text {** }}$ & 1 \\
\cline { 2 - 4 } & Sig. (2-tailed) & .000 & \\
\hline
\end{tabular}

Berdasarkan hasil pengujian diperoleh nilai korelasi sebesar 0,673 artinya kualitas pelayanan memiliki

Tabel 4. Hasil Pengujian Koefisien Korelasi Kualitas produk Terhadap Keputusan pembelian.

\begin{tabular}{llr|r} 
& \multicolumn{2}{c}{ Correlations $^{\mathbf{b}}$} & \multicolumn{2}{c}{$\begin{array}{c}\text { Kualitas } \\
\text { produk (X2) }\end{array}$} & \multicolumn{2}{c}{$\begin{array}{c}\text { Keputusan } \\
\text { pembelian (Y) }\end{array}$} \\
\hline Kualitas produk (X2) & Pearson Correlation & 1 & $.665^{\text {** }}$ \\
\cline { 2 - 4 } & Sig. (2-tailed) & & .000 \\
\hline $\begin{array}{l}\text { Keputusan pembelian } \\
\text { (Y) }\end{array}$ & Pearson Correlation & $.665^{\text {** }}$ & 1 \\
\cline { 2 - 4 } & Sig. (2-tailed) & .000 & \\
\hline
\end{tabular}

Berdasarkan hasil pengujian diperoleh nilai korelasi sebesar 0,665 artinya kualitas produk memiliki

hubungan yang kuat terhadap keputusan pembelian.

Tabel 5. Hasil Pengujian Koefisien Korelasi Kualitas pelayanan dan Kualitas produk secara simultan Terhadap Keputusan pembelian.

Model Summary

\begin{tabular}{lr|r|r|rr} 
Model & R & R Square & \multicolumn{1}{c|}{$\begin{array}{c}\text { Adjusted R } \\
\text { Square }\end{array}$} & \multicolumn{2}{c}{$\begin{array}{c}\text { Std. Error of the } \\
\text { Estimate }\end{array}$} \\
\hline 1 & $.732^{\mathrm{a}}$ & .536 & .527 & 2.463 \\
\hline
\end{tabular}

a. Predictors: (Constant), Kualitas produk (X2), Kualitas pelayanan (X1)

Berdasarkan hasil pengujian diperoleh nilai korelasi sebesar 0,732 artinya kualitas pelayanan dan kualitas produk secara simultan memiliki hubungan yang kuat

Tabel 6. Hasil Pengujian Koefisien Determinasi Kualitas pelayanan Terhadap Keputusan pembelian.

\section{Model Summary}

\begin{tabular}{|c|c|c|c|c|}
\hline \multicolumn{5}{|c|}{ Model Summary } \\
\hline Model & $\mathrm{R}$ & R Square & $\begin{array}{c}\text { Adjusted R } \\
\text { Square }\end{array}$ & $\begin{array}{l}\text { Std. Error of the } \\
\text { Estimate }\end{array}$ \\
\hline 1 & $.673^{a}$ & .45 & .44 & 2.66 \\
\hline
\end{tabular}

a. Predictors: (Constant), Kualitas pelayanan (X1)

Berdasarkan hasil pengujian diperoleh nilai determinasi sebesar 0,453 artinya kualitas pelayanan terhadap keputusan pembelian.

c. Analisis Koefisien Determinasi

Hasil pengujian koefisien determinasi sebagai berikut:

hubungan yang kuat terhadap keputusan pembelian. 
Tabel 7. Hasil Pengujian Koefisien Determinasi Kualitas produk Terhadap Keputusan pembelian.

Model Summary

\begin{tabular}{|c|c|c|c|c|}
\hline \multicolumn{5}{|c|}{ Hodel summary } \\
\hline Model & $\mathrm{R}$ & R Square & $\begin{array}{l}\text { Adjusted R } \\
\text { Square }\end{array}$ & $\begin{array}{l}\text { Std. Error of the } \\
\text { Estimate }\end{array}$ \\
\hline 1 & $.665^{a}$ & .442 & .436 & 2.68 \\
\hline
\end{tabular}

a. Predictors: (Constant), Kualitas produk (X2)

Berdasarkan hasil pengujian memiliki kontribusi pengaruh sebesar diperoleh nilai determinasi sebesar 0,442 artinya kualitas produk $44,2 \%$ terhadap keputusan pembelian.

Tabel 8. Hasil Pengujian Koefisien Determinasi Kualitas pelayanan dan Kualitas produk Terhadap Keputusan pembelian.

Model Summary

\begin{tabular}{|c|c|c|c|c|}
\hline Model & $\mathrm{R}$ & R Square & $\begin{array}{l}\text { Adjusted R } \\
\text { Square }\end{array}$ & $\begin{array}{l}\text { Std. Error of the } \\
\text { Estimate }\end{array}$ \\
\hline 1 & $.732^{\mathrm{a}}$ & .536 & .527 & 2.463 \\
\hline
\end{tabular}

a. Predictors: (Constant), Kualitas produk (X2), Kualitas pelayanan (X1)

Berdasarkan hasil pengujian diperoleh nilai determinasi sebesar 0,536 artinya kualitas pelayanan dan kualitas produk secara simultan memiliki kontribusi pengaruh sebesar $53,6 \%$ terhadap keputusan pembelian, sedangkan sisanya sebesar $46,4 \%$ dipengaruhi faktor lain.

\section{d. Uji Hipotesis}

\section{Uji hipotesis Parsial (Uji t)}

Pengujian hipotesis dengan uji $t$

Tabel 9. Hasil Uji Hipotesis Kualitas pelayanan Terhadap Keputusan pembelian.

\begin{tabular}{|c|c|c|c|c|c|}
\hline \multirow[b]{3}{*}{ Model } & \multicolumn{3}{|c|}{ Coefficients $^{a}$} & \multirow[b]{3}{*}{$\mathrm{t}$} & \multirow[b]{3}{*}{ Sig. } \\
\hline & \multicolumn{2}{|c|}{$\begin{array}{l}\text { Unstandardized } \\
\text { Coefficients }\end{array}$} & \multirow{2}{*}{$\begin{array}{c}\text { Standardized } \\
\text { Coefficients } \\
\text { Beta } \\
\end{array}$} & & \\
\hline & B & Std. Error & & & \\
\hline 1 (Constant) & 16.314 & 2.511 & & 6.497 & .000 \\
\hline $\begin{array}{l}\text { Kualitas pelayanan } \\
(\mathrm{X} 1)\end{array}$ & .594 & .066 & .673 & 9.001 & .000 \\
\hline
\end{tabular}

a. Dependent Variable: Keputusan pembelian (Y)

Berdasarkan hasil pengujian pada tabel di atas, diperoleh nilai $\mathrm{t}$ hitung $>\mathrm{t}$ tabel atau $(9,001>1,984)$, dengan demikian hipotesis pertama

Tabel 10. Hasil Uji Hipotesis Kualitas produk Terhadap Keputusan pembelian.

\section{Coefficients $^{\mathrm{a}}$}

\begin{tabular}{|c|c|c|c|c|c|}
\hline \multirow[b]{2}{*}{ Model } & \multicolumn{2}{|c|}{$\begin{array}{l}\text { Unstandardized } \\
\text { Coefficients }\end{array}$} & \multirow{2}{*}{$\begin{array}{l}\text { Standardized } \\
\text { Coefficients } \\
\text { Beta }\end{array}$} & \multirow[b]{2}{*}{$\mathrm{t}$} & \multirow[b]{2}{*}{ Sig. } \\
\hline & $\mathrm{B}$ & Std. Error & & & \\
\hline 1 (Constant) & 14.105 & 2.816 & & 5.009 & .000 \\
\hline Kualitas produk (X2) & .646 & .073 & .665 & 8.806 & .000 \\
\hline
\end{tabular}

a. Dependent Variable: Keputusan pembelian (Y) digunakan untuk mengetahui hipotesis parsial mana yang diterima. Hipotesis pertama: Terdapat pengaruh yang signifikan kualitas pelayanan terhadap keputusan

Hipotesis kedua: Terdapat pengaruh yang signifikan kualitas produk terhadap keputusan pembelian. pembelian.

yang diajukan bahwa terdapat pengaruh yang signifikan atara kualitas pelayanan terhadap keputusan pembelian diterima.

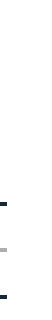


Berdasarkan hasil pengujian pada tabel di atas, diperoleh nilai $\mathrm{t}$ hitung $>\mathrm{t}$ tabel atau $(8,806>1,984)$, dengan demikian hipotesis kedua yang diajukan bahwa terdapat pengaruh yang signifikan atara kualitas produk terhadap keputusan pembelian diterima.
Uji Hipotesis Simultan (Uji F)

Pengujian hipotesis dengan uji $\mathrm{F}$ digunakan untuk mengetahui hipotesis simultan yang mana yang diterima.

Hipotesis ketiga Terdapat pengaruh yang signifikan antara kualitas pelayanan dan kualitas produk terhadap keputusan pembelian.

Tabel 11. Hasil Uji Hipotesis Kualitas pelayanan dan Kualitas produk Terhadap Keputusan pembelian.

ANOVA $^{a}$

\begin{tabular}{ll|r|r|r|r|r}
\multicolumn{1}{l}{ Model } & Sum of Squares & \multicolumn{1}{c|}{ df } & Mean Square & F & Sig. \\
\hline \multirow{2}{*}{1} & Regression & 680.277 & 2 & 340.138 & 56.081 & $.000^{\mathrm{b}}$ \\
\cline { 2 - 7 } & Residual & 588.313 & 97 & 6.065 & & \\
\cline { 2 - 7 } & Total & 1268.590 & 99 & & & \\
\hline
\end{tabular}

Berdasarkan hasil pengujian pada tabel di atas, diperoleh nilai $\mathrm{F}$ hitung > F tabel atau $(56,081>2,700)$, dengan demikian hipotesis ketiga yang diajukan bahwa terdapat pengaruh yang signifikan atara kualitas pelayanan dan kualitas produk terhadap keputusan pembelian diterima.

\section{PEMBAHASAN HASIL PENELITIAN}

1. Pengaruh Kualitas pelayanan

Terhadap Keputusan pembelian

Dari hasil analisis diperoleh variabel kualitas pelayanan berpengaruh signifikan terhadap keputusan pembelian dengan nilai korelasi sebesar 0,673 artinya kedua variabel memiliki hubungan yang kuat dengan kontribusi pengaruh sebesar 45,3\%. Pengujian hipotesis diperoleh nilai $\mathrm{t}$ hitung $>\mathrm{t}$ tabel atau $(9,001>1,984)$. Dengan demikian hipotesis pertama yang diajukan bahwa terdapat berpengaruh signifikan antara kualitas pelayanan terhadap keputusan pembelian diterima.

2. Pengaruh Kualitas produk Terhadap Keputusan pembelian

Dari hasil analisis diperoleh variabel kualitas produk berpengaruh signifikan terhadap keputusan pembelian dengan nilai korelasi sebesar
0,665 artinya kedua variabel memiliki hubungan yang kuat dengan kontribusi pengaruh sebesar 44,2\%. Pengujian hipotesis diperoleh nilai $\mathrm{t}$ hitung $>\mathrm{t}$ tabel atau $(8,806>1,984)$. Dengan demikian hipotesis kedua yang diajukan bahwa terdapat berpengaruh signifikan antara kualitas produk terhadap keputusan pembelian diterima.

3. Pengaruh Kualitas pelayanan dan Kualitas produk Terhadap Keputusan pembelian

Dari hasil analisis diperoleh variabel kualitas pelayanan dan kualitas produk berpengaruh signifikan terhadap keputusan pembelian dengan diperoleh persamaan regresi $Y=10,553+0,365 X 1+$ $0,378 \times 2$, nilai korelasi sebesar 0,732 artinya kedua variabel memiliki hubungan yang kuat dengan kontribusi pengaruh sebesar 53,6\% sedangkan sisanya sebesar $46,4 \%$ dipengaruhi faktor lain. Pengujian hipotesis diperoleh nilai $\mathrm{F}$ hitung > F tabel atau $(56,081>2,700)$. Dengan demikian hipotesis ketiga yang diajukan bahwa terdapat berpengaruh signifikan antara kualitas pelayanan dan kualitas produk terhadap keputusan pembelian diterima. 


\section{PENUTUP}

\section{Kesimpulan}

a. Kualitas pelayanan berpengaruh signifikan terhadap keputusan pembelian nilai korelasi sebesar 0,673 atau kuat dengan kontribusi pengaruh sebesar $45,3 \%$. Uji hipotesis diperoleh nilai $\mathrm{t}$ hitung $>\mathrm{t}$ tabel atau $(9,001>1,984)$. Dengan demikian terdapat pengaruh yang signifikan antara kualitas pelayanan terhadap keputusan pembelian pada PT. Panca Sakti Perkasa di Bintaro.

b. Kualitas produk berpengaruh signifikan terhadap keputusan pembelian dengan nilai korelasi sebesar 0,665 atau kuat dengan kontribusi pengaruh sebesar $44,2 \%$. Uji hipotesis diperoleh nilai t hitung > $t$ tabel atau $(8,806>1,984)$. Dengan demikian terdapat pengaruh yang signifikan antara kualitas produk terhadap keputusan pembelian pada PT. Panca Sakti Perkasa di Bintaro.

c. Kualitas pelayanan dan kualitas produk berpengaruh signifikan terhadap keputusan pembelian dengan nilai korelasi sebesar 0,732 atau kuat dengan kontribusi pengaruh sebesar $53,6 \%$ sedangkan sisanya sebesar $46,4 \%$ dipengaruhi faktor lain. Uji hipotesis diperoleh nilai $\mathrm{F}$ hitung $>\mathrm{F}$ tabel atau $(56,081>$ 2,700). Dengan demikian terdapat pengaruh yang signifikan antara kualitas pelayanan dan kualitas produk secara simultan terhadap keputusan pembelian pada PT. Panca Sakti Perkasa di Bintaro.

\section{Saran}

a. Bagi perusahaan hendaknya memperhatikan bagian dari yang di dalam kualitas produk dan kualitas layanan, karena sangat penting sekali agar dapat meningkatkan kepuasan yang dirasakan oleh konsumen, sehingga dapat menciptakan citra positif perusahaan dalam benak konsumen. Hal ini dapat berpengaruh terhadap meningkatnya volume penjualan.

b. Bagi para peneliti yang berminat untuk mengkaji dan meniliti ulang penelitian ini, disarankan lebih memperdalam dan memperluas variabel penelitian, indikator penelitian memperluas wilayah kajian penelitian serta memperdalam kerangka teoritis. Hal ini dikarenakan perhitungan yang menunjukkan bahwa masih banyaknya variabel lain yang belum diteliti sehingga memberikan peluang yang besar bagi peneliti lain untuk mengembangkan lebih lanjut.

\section{DAFTAR PUSTAKA}

Aaker. 2008. Managemen Ekuitas Merek, alih bahasa Aris Ananda. B a nd ung: Mitra Utama.

Agung W, Abul Harits. 2013. Analisis Pengaruh Kualitas Produk, Kualitas Layanan, Harga dan Brand Image Terhadap Keputusan Pembelian Konsumen Mie Setan Jember. Skripsi. Fakultas Ekonomi Universitas Jember, Jember.

Algifari. (2015). “Analisis Regresi untuk Bisnis dan Ekonomi". Yogyakarta: BPFE.

Arikunto, Suharsimi (2014). "Prosedur Penelitian Suatu Pendekatan Praktek". Jakarta: Rineka Cipta.

Buchari, Alma. 2001. Manajemen Pemasaran dan Pemasaran Jasa. Alfabeta.

Cannon, Perreault \& McCarthy, 2008, Pemasaran Dasar Pendekatan Manajerial

Edi Sutrisno (2016). Manajemen Sumber Daya Manusia. Jakarta: Prenadamedia Group.

Erlangga, H, et al. (2019). Pengaruh Kegiatan Promosi Terhadap Keputusan Pembelian Konsumen Pada PT. Modise Busana Sejati Di Bandung. Jurnal Ekonomi Efektif, 1(4).

Erlangga, H. (2021). Effect Of Digital Marketing And Social Media On Purchase Intention Of Smes Food Products. Turkish Journal of Computer and Mathematics Education (TURCOMAT), 12(3), 3672-3678. 
Erlangga, H., et al. (2020). Pharmaceutical Business Competition in Indonesia: A Review. Systematic Reviews in Pharmacy, 11(10), 617-623.

Fandy Tjiptono (2017), Serivce Quality and Satisfiation. Jakarta: Edisi tiga. Andi.

Ferdinand, Augusty. 2006. Structural Equation Modelling dalam Penelitian Manajemen, Aplikasi Model-model Rumit dalam Penelitian untuk Tesis dan Desertasi Doktor. Badan Penerbit Universitas Diponegoro. Semarang.

Freddy Rangkuti (2016) Strategi Promosi Yang Kreatif, Edisi Pertama, Cetakan Pertama Jakarta: Gramedia Pustaka Utama

Freed Luthans (2016) Organizational Behavior, McGraw-Hill, New York.

Gerry Dessler (2016) Human Resources Management, Prenticehall, London: International Inc.

Ghozali, Imam. 2006. Aplikasi Analisis Multivariate Dengan Program SPSS. Badan

Griffin R.W., \& Ronald, J.E. (2003). DasarDasar Pemasaran. Jakarta: Raja

Hair, et al. 1998. Multivariate Data Analysis, Fifth Edition. Prentice Hall, Upper

Handoko (2016) Manajemen Personalia dan Sumberdaya Manusia. Yogyakarta: BPFE.

Haque, M. G., et al. (2021). Micro Financial Sharia Non-bank Strategic Analysis: a Study at BMT Beringharjo, Yogyakarta. Budapest International Research and Critics Institute (BIRCI-Journal): Humanities and Social Sciences, 4(2), 1677-1686.

Haque, M. G., Munawaroh, M., Sunarsi, D., \& Baharuddin, A. (2021). Competitive Advantage in Cost Leadership and Differentiation of SMEs "Bakoel Zee" Marketing Strategy in BSD. PINISI Discretion Review, 4(2), 277-284.

Hasibuan (2016) "Manajemen Sumber Daya Manusia". Haji Masagung. Jakarta.

Henry Simamora (2005), Manajemen Sumber Daya Manusia, STIE YKPN Bandung.

Hurriyati, Ratih. 2015. Bauran Pemasaran dan Loyalitas Konsumen. Alfabeta, Bandung.
Imam Ghozali (2017). "Aplikasi Analisis Multivariate Dengan Program SPSS". Edisi Kelima. Semarang: Badan Penerbit Undip.

Irawan D, Handi. 2002. Sepuluh Prinsip Keputusan Pelanggan, Cetakan. Jakarta: pertama.

Istijanto (2014) "Riset Sumber Daya Manusia". Jakarta: PT. Gramedia Pustaka

Jasmani, Jasmani, and Denok Sunarsi. "The Influence of Product Mix, Promotion Mix and Brand Image on Consumer Purchasing Decisions of Sari Roti Products in South Tangerang." PINISI Discretion Review 1.1 (2020): 165-174.

Kartini Kartono (2011) Pemimpin dan Kepemimpinan, Jakarta: PT. Rajawaligrafindo Persada.

Kasmad, K., et al. (2020). Increasing Community School Interest Through Service Quality, Prices and Promotion in Vocational High Schools. Journal of Educational Science and Technology (EST), 6(2).

Kevin Keller dan Amstrong (2017) Prinsipprinsip Pemasaran, Edisi Kedua Belas, Jilid Satu, Jakarta: Erlangga.

Kharis, Ismu Fadli (2011). "Studi Mengenai Impulse Buying dalam Penjualan Online". Semarang : Skripsi Universitas Diponegoro

Kotler \& Keller (2016) "Manajemen Pemasaran". PT. Macaman Jaya Cemerlang. Jakarta.

Kotler (2016) "Manajemen Pemasaran". Edisi Keempat belas, Jakarta: PT. Indeks.

Kotler Philip, Keller Kevin Lane. 2008. Manajemen Pemasaran, Jilid 1. Alih bahasa oleh Bob Sabran, MM. Edisi Ketiga belas. Erlangga. Jakarta.

Kurniawan, Tomi. 2013. Analisis Pengaruh Kualitas Produk,Kualitas Pelayanan dan Lokasi Terhadap Keputusan Pembelian Motor Matic Suzuki di Raharjo Motor Jepara. Skripsi. Fakultas Ekonomi Universitas Diponegoro. Semarang.

Lupiyadi, Rambat (2016) Manajemen Pemasaran Jasa edisi 2 , Jakarta : Salemba Empat.

Lupiyoadi (2016) Manajemen Pemasaran Jasa, 
Edisi 4, Jakarta: Salemba Empat.

Maddinsyah, A., et al. (2020). Desain Formulasi

Dan Implementasi Bisnis Strategik

Dengan Pendekatan Business Model

Canvas (BMC) Terintegrasi Kerangka Integrated Performance Management System (IPMS) Pada Koperasi Asperindo. Inovasi, 7(2), 67-76.

Mangkunegara, Prabu Anwar. (2016). Evaluasi Kinerja SDM. Cetakan ke tujuh, PT Refika Aditama: Bandung.

Nurjaya, N., Affandi, A., Erlangga, H., Sunarsi, D., \& Jasmani, J. (2021). The Effect of Product Promotion and Innovation Activities on Marketing Performance in Middle Small Micro Enterprises in Cianjur. Budapest International Research and Critics Institute (BIRCI-Journal): Humanities and Social Sciences, 4(1), 528-540.

Philip Kotler (2017) Manajemen Pemasaran, Edisi Keempat Belas, Jakarta: PT. Indeks.

Purwanti, Y. (2021). The Influence Of Digital Marketing \& Innovasion On The School Performance. Turkish Journal of Computer and Mathematics Education (TURCOMAT), 12(7), 118-127.

Purwanto, A., et al. (2021). The Role of Brand Image, Food Safety, Awareness, Certification on Halal Food Purchase Intention: An Empirical Study on Indonesian Consumers. Journal of Industrial Engineering \& Management Research, 2(3), 42-52.
Purwanto, H., et al (2020). Developing Model of Halal Food Purchase Intention among Indonesian Non-Muslim Consumers: An Explanatory Sequential Mixed Methods Research. Systematic Reviews in Pharmacy, 11(10), 396-407.

Rao, Purba, (2012). "Measuring Consumer Perceptions Through Factor Analysis", The Asian.

Rivai Veithzal (2015) Manajemen Sumber Daya Manusia Untuk Perusahaan. Jakarta: PT Raja Grafindo Persada.

Santoso, Singgih (2015). “Menguasai Statistik Multivariat". Jakarta: PT Elex Media Komputindo.

Sedarmayanti (2016) Manajemen Sumber Daya Manusia, Reformasi Birokrasi dan Manajemen Karyawan Negeri Sipil, Cetakan Kelima, Bandung: PT Refika Aditama.

Siagian, S (2007). Manajemen Sumber Daya Manusia. Jakarta: Bumi Aksara.

Sinamo, J. (2011). Delapan Etos Kerja Profesional. Jakarta: Institut

Sudjana (2014) "Metode Statistika", Bandung: Tarsido.

Sugiyono (2017), "Metode Penelitian Administrasi : dilengkapi dengan Metode $R \mathcal{E} D^{\prime \prime}$. Bandung: Alfabeta.

Suhartanto (2014). "Metode Riset Pemasaran". Bandung: Alfabeta.

Syobar, K., et al. (2020). The Effect of Service Quality and Price on Purchase Decisions in Woodpecker Coffee in South Jakarta. Solid State Technology, 63(6), 1491-1504. 